\title{
Effects of supercritical fluid extraction pressure on chemical composition, microbial population, polar lipid profile, and microstructure of goat cheese
}

\author{
D. Sánchez-Macías, ${ }^{*}$ A. Laubscher, $†$ N. Castro, $\ddagger$ A. Argüello, $\ddagger^{1}$ and R. Jiménez-Flores $†$ \\ *Agricultural and Livestock Engineering Faculty, Universidad Estatal del Sur de Manabí, Jipijapa130650, Manabí, Ecuador \\ †Dairy Products Technology Center, California Polytechnic State University, San Luis Obispo 93401 \\ ‡Department of Animal Science, Universidad de Las Palmas de Gran Canaria, Arucas 35413, Spain
}

\section{ABSTRACT}

The consumer trend for healthier food choices and preferences for low-fat products has increased the interest in low-fat cheese and nutraceutical dairy products. However, consumer preference is still for delicious food. Low- and reduced-fat cheeses are not completely accepted because of their unappealing properties compared with full-fat cheeses. The method reported here provides another option to the conventional cheesemaking process to obtain lower fat cheese. Using $\mathrm{CO}_{2}$ as a supercritical fluid offers an alternative to reduce fat in cheese after ripening, while maintaining the initial characteristics and flavor. The aim of this experiment was to evaluate the effect of pressure $(10,20,30$, and $\left.40 \times 10^{6} \mathrm{~Pa}\right)$ of supercritical $\mathrm{CO}_{2}$ on the amount of fat extracted, microbial population, polar lipid profile, and microstructure of 2 varieties of goat cheese: Majorero, a protected denomination of origin cheese from Spain, and goat Gouda-type cheese. The amount of fat was reduced 50 to $57 \%$ and 48 to $55 \%$ for Majorero and goat Gouda-type cheeses, respectively. Higher contents (on a fat basis) of sphingomyelin and phosphatidylcholine were found in Majorero cheese compared with control and goat Gouda-type cheeses. The microbial population was reduced after supercritical fluid extraction in both cheeses, and the lethality was higher as pressure increased in Majorero cheese, most noticeably on lactococcus and lactobacillus bacteria. The Gouda-type cheese did not contain any lactobacilli. Micrographs obtained from confocal laser scanning microscopy showed a more open matrix and whey pockets in the Majorero control cheese. This could explain the ease of extracting fat and reducing the microbial counts in this cheese after treatment with supercritical $\mathrm{CO}_{2}$. Supercritical fluid extraction with $\mathrm{CO}_{2}$ has great potential in the dairy industry and in commercial applications. The Majorero cheese obtained after the supercritical fluid extraction

Received February 27, 2012.

Accepted October 24, 2012.

${ }^{1}$ Corresponding author: aarguello@dpat.ulpgc.es treatment was an excellent candidate as a low-fat goat cheese, lower in triglycerides and cholesterol but still with all the health benefits inherent in goat milk.

Key words: goat cheese, supercritical fluid extraction, microstructure, phospholipid

\section{INTRODUCTION}

Lipids are vital components of our diet; however, consumption of saturated fat is highly correlated with increased risk of obesity, atherosclerosis, coronary artery disease, and elevated blood pressure (Watts et al., 1996; Van Horn and Ernest, 2001). Largely influenced by an increase in consumer concerns, the food industry has been pressured to develop reduced-fat products. Although strict low-fat diets are not universally adopted, trends for healthier food choices and consumer preference for low-fat products have increased the interest in low-fat cheese (Johansen et al., 2011). The food industry is aware of consumer desire to purchase delicious, convenient, and nutritious food and, with this in mind, cheese has been proposed as a potential solid nutrient matrix. Cheese can be used as a vector of bioactive components to improve nutrition and health of consumers (Turgeon and Rioux, 2011).

In full-fat cheese, weak spots in the discontinuous protein matrix are created, which improves the chewability of the cheese (Johnson et al., 2009). In low-fat cheese, the protein matrix is more compact (McMahon et al., 1996; Aryana and Haque, 2001; Rahimi et al., 2007). Some researchers (Gwartney et al., 2002; Brown et al., 2003; Yates and Drake, 2007) have reported that reduced-fat cheeses are characterized by chewiness, hardness, firmness, fracturability, and springiness, and they display lower cohesiveness. Recently, SánchezMacías et al. (2010) reported significant differences in physicochemical composition and instrumental texture profile of full-fat goat cheese and their counterpart lowand reduced-fat goat cheeses.

Proteolysis contributes to cheese ripening through a direct contribution to flavor and texture (Sousa et al., 2001). In low-fat goat cheeses, proteolysis of casein is 
inadequate (Sánchez-Macías et al., 2011), resulting in a relatively firm texture and higher instrumental hardness and masticability (Sánchez-Macías et al., 2010). On the other hand, lipolysis in cheese produces FFA, which have long been considered responsible for the characteristic aroma of goat cheeses. Hexanoic, octanoic, and decanoic fatty acids are considered responsible for the characteristic aroma of goat (caprine) cheeses, giving rise to their common names - caproic, caprylic, and capric acids, respectively. Certain branched-chain FFA also contribute to the "goaty" flavor of cheese (Salles et al., 2002). The lack of fat and the faster liberation of FFA from the remaining fat in low- and reducedfat cheese (Sánchez-Macías et al., 2011) may promote early FFA metabolism and thus modify the flavor that is characteristic of full-fat goat cheese. Drake (2008), Childs and Drake (2009), and Sánchez-Macías et al. (2012) evaluated consumer acceptance of low-fat cow and goat cheeses; consumers perceive these to be unnatural and unappealing compared with full-fat cheeses.

Several methods have been used to modify and improve the texture of low-fat cheese. Alteration of cheesemilk processing conditions, modification of cheese-making procedure (Mistry, 2001; Guinee and McSweeney, 2006), inclusion of additives and fat replacers (Larsen, 2009), and the use of starter strains that produce exopolysaccharides have been proposed as mechanisms to improve the quality of reduced-fat cheeses (Awad et al., 2005; Dabour et al., 2006; Jiménez-Gúzman et al., 2009). However, full-fat cheeses have always been more accepted than their lower fat counterparts.

One approach that has not been explored fully is to manufacture a full-fat, flavorful, matured cheese and then remove the fat from the product. Nelson and Barbano (2004) removed 55\% of the fat content in Cheddar cheese by using a centrifugal fat-removal process. Supercritical fluid extraction (SFE) technology offers a less destructive alternative to fat extraction. Fat removal in sample matrices is based on lipid solubility in the solvent - carbon dioxide in this case - without any harmful chemical residues (Nielsen, 2003a). Carbon dioxide is the most commonly used supercritical fluid because of its mild critical properties $\left(31^{\circ} \mathrm{C}\right.$ and $7.3 \times$ $10^{6}$ Paof pressure) and because it offers easy separation of the processed products under ambient conditions. Carbon dioxide is also cheap, available at high purity, and considered a "green" solvent. Supercritical carbon dioxide $\left(\mathbf{S C}-\mathbf{C O}_{2}\right)$ is an ideal solvent for removing lipids such as triglycerides and cholesterol from cheese matrices because of its behavior as a nonpolar solvent (Arul et al., 1994; Yee, 2006). Yee et al. (2007) suggested that SFE technology can be used in the dairy industry to develop cheese products with lower fat that still retain flavor compounds that may not typically fully develop with alternative methods of low-fat cheese processing.

Currently, consumer demand for a diversification of cheese products has focused on small ruminant cheeses. Ewe and goat milk products can provide a profitable alternative to cow milk products because of their specific composition, sensory qualities, and inherent healthpromoting attributes (Haenlein, 2004; Raynal-Ljutovac et al., 2008; Ribeiro and Ribeiro, 2010). Cheese is an important part of the economy and traditions of the Canary Islands (Spain): about 17,000 t of goat milk cheese is produced per year (Fresno et al., 2008). The Canary Islands have a variety of cheeses, and Majorero cheese, made with pure goat milk, is one of the most important. However, no low-fat cheeses from the Canary Islands are made and sold in the market. Goat milk Gouda-type cheese is available as an alternative to its cow milk counterpart. It was chosen for this experiment because of its similarity to Majorero cheese based on gross composition (protein and moisture content), sensorial hardness and firmness, and type of rennet used during the cheese making.

The objective of this study was to evaluate the influence of 4 different pressures in a dynamic flow of $1,000 \mathrm{~g}$ of $\mathrm{SC}-\mathrm{CO}_{2}$ at $35^{\circ} \mathrm{C}$ on the chemical composition, especially the amount of fat removed, microbial inactivation, lipid profile, and microstructure of goat Gouda-type and Majorero cheese aged over 5 mo.

\section{MATERIALS AND METHODS}

\section{Experimental Design}

Cheese samples as controls were taken from samples kept at $4^{\circ} \mathrm{C}$ and $35^{\circ} \mathrm{C}$ for $50 \mathrm{~min}$. The variable parameters of the process were treatment pressure $(10,20$, 30 , and $40 \times 10^{6} \mathrm{~Pa}$ ) and cheese type (Gouda-type and Majorero goat cheeses). The treatments were as follows: cheese held at $4^{\circ} \mathrm{C}$ (control); control cheese held in an incubator at $35^{\circ} \mathrm{C}$ for $50 \mathrm{~min}$, and cheese treated with SC- $\mathrm{CO}_{2}$ at $10(\mathbf{P} 10), 20(\mathbf{P} 20), 30(\mathbf{P 3 0})$, or $40(\mathbf{P 4 0})$ $\times 10^{6} \mathrm{~Pa}$; each treatment was carried out in triplicate. In total, 36 samples were collected: 6 treatments $\times 2$ cheese varieties $\times$ triplicate analysis.

\section{Sample Preparation}

Commercial goat milk Gouda-type cheese from the Netherlands and Majorero cheese from the Canary Islands (Spain) aged over 5 mo were purchased for these experiments. Approximately $100 \mathrm{~g}$ of hand-grated cheese was carefully weighed on an analytical balance separately and then evenly distributed into filter bags (Filter Fabrics Inc., Goshen, IN), sealing both ends of 
the bag. After processing, the cheese samples were removed from the filter bag and reweighed to determine the yield of finished processed cheese.

\section{Supercritical Fluid Extraction}

The SFE unit used was a laboratory-scale SFE system (model SFE 500; Thar Technologies Inc., Pittsburgh, PA) with an extraction volume of up to $500 \mathrm{~mL}$, maximum flow rate of $50 \mathrm{~g} / \mathrm{min}$, maximum operating pressure of $60 \times 10^{6} \mathrm{~Pa}$, maximum temperature of $150^{\circ} \mathrm{C}$, cyclone separator capacity of $500 \mathrm{~mL}$, including an automated back pressure regulator (model ABPR200, Thar Technologies). The carbon dioxide tanks used for extraction were supplied by Air Gas (50 lb., San Luis Obispo, CA). The process unit was operated in the dynamic mode, which allowed the sample to be continuously supplied with fresh $\mathrm{SC}-\mathrm{CO}_{2}$. The flow rate was kept constant at $20 \mathrm{~g} / \mathrm{mL}$. A total of 1,000 $\mathrm{g}$ of $\mathrm{CO}_{2}$ was allowed to run when the desirable pressure was reached, equivalent to 50 min of treatment.

\section{Cheese Compositional Analysis}

Fat content of cheese samples was determined by the Babcock method for cheese according to the Standard Methods for the Examination of Dairy Products (Bradley et al., 1992). Protein content in cheese samples was determined by the Kjeldahl method (AOAC International, 1995; method 920.123). Moisture and solids contents in samples were measured using AOAC International (1995) method 977.11 for cheese (microwave oven; Nielsen, 2003b) utilizing a LabWave 9000 Microwave Moisture/Solids Analyzer (CEM Corp., Matthews, NC). Each analysis was conducted in duplicate and the average was taken as the sample value.

\section{Lipid Characterization}

Thin layer chromatography was used to chemically analyze the lipid profile of the cheese samples and the extracted fat from the cheese after SFE processing. Polar plates were run to characterize the polar lipid fractions such as phospholipids. Fat obtained by the Mojonnier test was used to obtain the lipid samples according to the Standard Methods for Examination of Dairy Products (Bradley et al., 1992). Lipid samples were diluted to $10 \mathrm{mg} / \mathrm{mL}$ with a chloroform:methanol (1:2, vol:vol) solvent mixture. Polar standards phosphatidylethanolamine, phosphatidylcholine, and sphingomyelin (all from Sigma Chemical Co., St. Louis, MO) were prepared at $2 \mathrm{mg} / \mathrm{mL}$ to detect specific phospholipids in cheeses. Cheese lipid samples from control, P10, P30, and P40 cheeses, the resulting extracted fat after the treatments, and the polar lipid standards were applied in $25-\mu \mathrm{L}$ amounts for all plates using a syringe. Precoated silica gel plates $(10 \times 20 \mathrm{~cm}$, EMD Chemicals Inc., Gibbstown, NJ) were used for separation. The plates were placed in a polar solvent tank consisting of chloroform:methanol:water (65:25:4, vol:vol:vol) and then developed with iodine (Sigma Chemicals Co.) to detect the polar lipids present in the samples.

\section{Microbiological Analysis}

To assess the microbial counts of cheeses, $10 \mathrm{~g}$ of each cheese sample was homogenized in a sterile plastic bag and mixed with $90 \mathrm{~mL}$ of $\mathrm{NaCl}$ solution $(0.9 \%)$ using a stomacher laboratory blender. The samples were serially diluted in saline and then plated on 3M Petrifilm Aerobic Count plates (3M Microbiology, St. Paul, MN) for aerobic bacteria, and on M17 and de Man, Rogosa, Sharpe agar for lactococci and lactobacilli, respectively, using standard pour-plate techniques. All plates were incubated at $30^{\circ} \mathrm{C}$ and the colonies were enumerated after 48 to $72 \mathrm{~h}$. The obtained results were expressed in $\log$ colony-forming units per gram of cheese.

\section{Microstructure of Cheese Samples}

Cheese samples were prepared and stained according to Lopez et al. (2007). Acridine orange fluorescent dye (1:500, vol:vol), to label the protein network, and lipid-soluble Nile Red fluorescent dye (20:500, vol:vol), to label the fat, were dissolved in acetone and mixed. About $0.5 \mathrm{~mL}$ of the mixed staining solution was placed on slices of cheese (approximately $5 \times 5 \times 3 \mathrm{~mm}$ ) in a concave glass slide. The solvents were evaporated in the dark, and then $20 \mu \mathrm{L}$ of $5 \%$ agar was added and a coverslip was put on the slide. The microstructural analysis was performed using an Olympus FV1000 inverted confocal laser scanning microscope (Olympus America Inc., Center Valley, PA), allowing confocal laser scanning microcopy (CLSM) in dual-beam fluorescent mode, with excitation wavelengths of 568 and $488 \mathrm{~nm}$ for fat and protein, respectively. Each cheese sample was subjected to CLSM, and at least 5 images from each sample were taken at the $400 \times$ level of magnification. The micrographs presented in this paper were considered representative of the different cheese samples analyzed.

\section{Statistical Analysis}

Statistical analyses were performed using SAS software (version 9.00, SAS Institute Inc., Cary, NC). The ANOVA procedure was used to compare control cheeses and those treated with $\mathrm{SC}-\mathrm{CO}_{2}$ to evaluate the effect 
of pressure level on yield, chemical composition, and microbiological counts. Significantly different means were identified using the Tukey test.

\section{RESULTS AND DISCUSSION}

\section{Yield and Chemical Composition of Cheese}

The yield and chemical composition of control cheeses and cheeses treated with $\mathrm{SC}-\mathrm{CO}_{2}$ were expressed in percentage values and are summarized in Table 1. Fifty minutes in the incubator resulted in a slightly lower weight in both cheese types, probably because of moisture evaporation during the experimental time, with no statistical differences between the 2 cheese types. As expected, the weights of samples were reduced after the SFE treatment.

Fat percentage was reduced in cheese samples after SFE. In Majorero goat cheese, the reduction was $>40 \%$ for P10, P20, and P30 and $45 \%$ for P40; for goat Gouda-type cheese, the reduction ranged from 36 to $40 \%$, with no statistical differences among the different pressure treatments. Protein and moisture percentages increased in both type of cheeses after SFE treatment because of the effect of fat reduction in the matrix.

Chemical composition, expressed in absolute values, was compared with the initial content, and differences were calculated as the loss of weight in samples after treatment (Table 2). In this way, we could evaluate the actual fat, protein, and moisture losses. Fat content was reduced between 50 and $57 \%(15.79-17.95 \mathrm{~g})$ and between 48 and $55 \%$ (17.60-19.46 g), in Majorero and goat Gouda-type cheeses, respectively. The reduction was higher as pressure increased for Majorero cheese, but no significant differences were found in the Goudatype cheese between the experimental pressures used. Using similar parameters for SFE $\left(35 \times 10^{6} \mathrm{~Pa}, 35^{\circ} \mathrm{C}\right.$, and $1,000 \mathrm{~g}$ of $\mathrm{CO}_{2}$ ), Yee et al. (2008) reported fat reductions of 24 to $25 \mathrm{~g}$ and 18 to $21 \mathrm{~g}$ of fat, respectively, in Cheddar (35\% of fat) and Parmesan (28\% fat) cheeses.

Protein content did not change in cheeses after SFE treatment compared with control cheese, as Yee et al. (2008) reported for the other cheese varieties. Moisture content was reduced after the $\mathrm{SC}-\mathrm{CO}_{2}$ treatment by 8 to $12 \%(3.86 \mathrm{~g})$ and by 10 to $12 \%$ (3.84 g) in Majorero and goat Gouda-type cheeses, respectively. Yee et al. (2008) found similar losses of moisture in cheese during the same exposure time to the SFE, which suggests that the moisture losses were independent of pressure, and were perhaps dependent on the exposure time to the dynamic flow of $\mathrm{SC}-\mathrm{CO}_{2}$. Yee et al. (2008) suggested that the moisture content in cheese may influence the supercritical fluid extraction of lipids, but they could not explain whether the differences in fat removed from cheese samples were due to differences in moisture or to cheese type. The current work evaluated cheeses with similar initial moisture contents; therefore, there exists a clear dependence of cheese variety on $\mathrm{CO}_{2} \mathrm{SFE}$. The initial fat content in cheese may have a role in the extraction of lipids with $\mathrm{SC}-\mathrm{CO}_{2}$, because the higher the fat content in cheese, the more fat is extracted.

Table 1. Yield and chemical composition in percentage of Majorero and goat Gouda-type control cheeses and cheeses treated with supercritical $\mathrm{CO}_{2}$ at 4 different pressures

\begin{tabular}{lccccccc}
\hline & \multicolumn{7}{c}{ Treatment $^{1}$} \\
\cline { 2 - 5 } Item & Control & CI & P10 & P20 & P30 & P40 & SEM \\
\hline Majorero cheese & & & & & & \\
Pretreatment weight, g & 100.03 & 100.06 & 100.10 & 100.09 & 100.02 & 100.03 & 0.07 \\
Posttreatment weight, g & $99.76^{\mathrm{a}}$ & $98.64^{\mathrm{a}}$ & $80.30^{\mathrm{b}}$ & $77.72^{\mathrm{c}}$ & $78.41^{\mathrm{bc}}$ & $77.79^{\mathrm{c}}$ & 0.72 \\
Fat, \% & $31.17^{\mathrm{a}}$ & $31.33^{\mathrm{a}}$ & $19.17^{\mathrm{b}}$ & $19.50^{\mathrm{b}}$ & $18.75^{\mathrm{bc}}$ & $17.00^{\mathrm{c}}$ & 0.69 \\
Protein, \% & $25.77^{\mathrm{c}}$ & $26.83^{\mathrm{c}}$ & $30.67^{\mathrm{b}}$ & $31.39^{\mathrm{ab}}$ & $31.47^{\mathrm{ab}}$ & $32.93^{\mathrm{a}}$ & 0.51 \\
Moisture, \% & $36.03^{\mathrm{b}}$ & $34.72^{\mathrm{b}}$ & $41.19^{\mathrm{a}}$ & $40.55^{\mathrm{a}}$ & $41.36^{\mathrm{a}}$ & $40.84^{\mathrm{a}}$ & 0.97 \\
Solids, \% & $64.30^{\mathrm{a}}$ & $65.28^{\mathrm{a}}$ & $58.81^{\mathrm{b}}$ & $59.45^{\mathrm{b}}$ & $58.64^{\mathrm{b}}$ & $59.16^{\mathrm{b}}$ & 0.88 \\
Fat in DM, \% & $48.48^{\mathrm{a}}$ & $48.00^{\mathrm{a}}$ & $32.60^{\mathrm{b}}$ & $32.80^{\mathrm{b}}$ & $31.98^{\mathrm{b}}$ & $28.76^{\mathrm{b}}$ & 1.44 \\
Goat Gouda-type cheese & & & & & & \\
Pretreatment weight, g & 100.05 & 100.03 & 100.03 & 100.01 & 100.02 & 100.03 & 0.09 \\
Posttreatment weight, g & $99.82^{\mathrm{a}}$ & $97.72^{\mathrm{a}}$ & $79.46^{\mathrm{b}}$ & $79.11^{\mathrm{b}}$ & $78.33^{\mathrm{bc}}$ & $76.72^{\mathrm{c}}$ & 0.82 \\
Fat, \% & $36.33^{\mathrm{a}}$ & $37.33^{\mathrm{a}}$ & $23.33^{\mathrm{b}}$ & $23.67^{\mathrm{b}}$ & $22.00^{\mathrm{b}}$ & $22.00^{\mathrm{b}}$ & 0.69 \\
Protein, \% & $24.72^{\mathrm{b}}$ & $25.00^{\mathrm{b}}$ & $29.20^{\mathrm{a}}$ & $30.05^{\mathrm{a}}$ & $29.64^{\mathrm{a}}$ & $30.97^{\mathrm{a}}$ & 0.53 \\
Moisture, \% & $35.64^{\mathrm{c}}$ & $34.67^{\mathrm{c}}$ & $40.13^{\mathrm{a}}$ & $40.65^{\mathrm{a}}$ & $40.85^{\mathrm{a}}$ & $40.65^{\mathrm{a}}$ & 0.70 \\
Solids, \% & $64.36^{\mathrm{a}}$ & $65.33^{\mathrm{a}}$ & $59.87^{\mathrm{b}}$ & $59.35^{\mathrm{b}}$ & $59.16^{\mathrm{b}}$ & $59.35^{\mathrm{b}}$ & 0.70 \\
Fat in DM, \% & $56.46^{\mathrm{a}}$ & $57.15^{\mathrm{a}}$ & $38.97^{\mathrm{b}}$ & $39.88^{\mathrm{b}}$ & $37.20^{\mathrm{b}}$ & $37.07^{\mathrm{b}}$ & 1.23 \\
\hline
\end{tabular}

${ }^{\mathrm{a}-\mathrm{c}}$ Means within a row with different superscripts differ $(P<0.05)$.

${ }^{1}$ Control $=$ cheese at $4{ }^{\circ} \mathrm{C}$; CI $=$ cheese in incubator at $35^{\circ} \mathrm{C}$ for $50 \mathrm{~min} ; \mathrm{P} 10, \mathrm{P} 20, \mathrm{P} 30$, and $\mathrm{P} 40=$ cheese treated with $1,000 \mathrm{~g}$ of supercritical $\mathrm{CO}_{2}$ at $35^{\circ} \mathrm{C}$ for $50 \mathrm{~min}$ at $10,20,30$, and $40 \times 10^{6} \mathrm{~Pa}$ of pressure, respectively. 
Table 2. Chemical composition of $100 \mathrm{~g}$ of Majorero and goat Gouda-type control cheeses and cheeses treated with supercritical $\mathrm{CO}_{2}$ at 4 different pressures

\begin{tabular}{llllllll}
\hline & \multicolumn{7}{c}{ Treatment $^{1}$} \\
\cline { 2 - 6 } Item & Control & CI & P10 & P20 & P30 & P40 & SEM \\
\hline Majorero cheese & & & & & & \\
Fat, g & $31.17^{\mathrm{a}}$ & $30.89^{\mathrm{a}}$ & $15.38^{\mathrm{b}}$ & $15.14^{\mathrm{bc}}$ & $14.70^{\mathrm{bc}}$ & $13.22^{\mathrm{c}}$ & 0.66 \\
Protein, g & $25.77^{\mathrm{ab}}$ & $26.45^{\mathrm{a}}$ & $24.60^{\mathrm{b}}$ & $24.33^{\mathrm{b}}$ & $24.67^{\mathrm{b}}$ & $25.61^{\mathrm{b}}$ & 0.34 \\
Moisture, g & $36.04^{\mathrm{a}}$ & $34.23^{\mathrm{ab}}$ & $33.04^{\mathrm{b}}$ & $31.49^{\mathrm{b}}$ & $32.43^{\mathrm{b}}$ & $31.76^{\mathrm{b}}$ & 0.95 \\
Solids, g & $64.30^{\mathrm{a}}$ & $64.36^{\mathrm{a}}$ & $47.17^{\mathrm{b}}$ & $46.16^{\mathrm{b}}$ & $45.97^{\mathrm{b}}$ & $46.00^{\mathrm{b}}$ & 0.79 \\
Goat Gouda-type cheese & & & & & & & \\
Fat, g & $36.33^{\mathrm{a}}$ & $36.47^{\mathrm{a}}$ & $18.53^{\mathrm{b}}$ & $18.73^{\mathrm{b}}$ & $17.23^{\mathrm{b}}$ & $16.87^{\mathrm{b}}$ & 0.67 \\
Protein, g & 24.73 & 24.42 & 23.19 & 23.78 & 23.21 & 23.75 & 0.07 \\
Moisture, g & $35.64^{\mathrm{a}}$ & $34.87^{\mathrm{a}}$ & $31.87^{\mathrm{b}}$ & $32.16^{\mathrm{b}}$ & $31.99^{\mathrm{b}}$ & $31.18^{\mathrm{b}}$ & 0.67 \\
Solids, g & $64.36^{\mathrm{a}}$ & $63.82^{\mathrm{a}}$ & $47.56^{\mathrm{b}}$ & $46.95^{\mathrm{b}}$ & $46.32^{\mathrm{b}}$ & $45.52^{\mathrm{b}}$ & 0.87 \\
\hline
\end{tabular}

${ }^{\mathrm{a}-\mathrm{c}}$ Means within a row with different superscripts differ $(P<0.05)$.

${ }^{1}$ Control $=$ cheese at $4{ }^{\circ} \mathrm{C}$; CI $=$ cheese in incubator at $35^{\circ} \mathrm{C}$ for $50 \mathrm{~min}$; $\mathrm{P} 10, \mathrm{P} 20, \mathrm{P} 30$, and $\mathrm{P} 40=$ cheese treated with $1,000 \mathrm{~g}$ of supercritical $\mathrm{CO}_{2}$ at $35^{\circ} \mathrm{C}$ for $50 \mathrm{~min}$ at $10,20,30$, and $40 \times 10^{6} \mathrm{~Pa}$ of pressure, respectively.

\section{Selectivity of Lipid Extraction}

The polar lipid profiles of cheeses are shown in Figure 1. In order to detect lipid retention in the cheese matrix, we used polar lipid standards consisting of the 3 main bovine milk fat globule membrane phospholipids: phosphatidylethanolamine, phosphatidylcholine, and sphingomyelin (Spitsberg, 2005).

In this experiment, the higher content of the main phospholipids found in the Majorero goat control cheese compared with the goat Gouda-type control cheese was quite remarkable. Both sphingomyelin and phosphatidylcholine were detected in Majorero cheese, whereas no phosphatidylcholine and minimal amounts of sphingomyelin were detected in Gouda cheese samples after SFE. No phosphatidylethanolamine was detected in either cheese. Yee et al. (2007) observed that Cheddar and Parmesan cow milk cheese treated with $\mathrm{SC}-\mathrm{CO}_{2}$ contained all 3 types of phospholipids. These phospholipid results are in conflict with previous reports (MacGibbon and Taylor, 2006). Those authors reviewed the different phospholipid proportions in milk and reported that phosphatidylcholine, phosphatidylethanolamine, and sphingomyelin are found in similar proportions in various animal species, including cow and goat milk.

Analyzing the phospholipid contents in different dairy products, Rombaut et al. (2007) confirmed that ruptured membrane parts will preferentially migrate to the serum phase, altering the phospholipid:lipid ratio in cheese. This can be noticed when examining the data from cheese, whey, cream, butter, and buttermilk. During cheese making specifically, the fat is concentrated in the curd, the milk fat globule membrane is damaged, and then fragments migrate to the cheese whey. As such, the phospholipid content expressed on a fat basis of raw or full-fat milk (0.6-0.7\%) will be slightly higher than that of full-fat cheeses (0.4-0.6\%), but much lower than that in whey $(5.3-6.2 \%)$ or derived whey products such as ricotta $(2.7 \%)$. The lower phospholipid presence in goat Gouda-type cheese was entirely unexpected, and the reason is unclear.

Analysis of the fat removed from the cheese after $\mathrm{SFE}$ with $\mathrm{CO}_{2}$ showed that only triglycerides and cholesterol were extracted by $\mathrm{SC}-\mathrm{CO}_{2}$ (Figure 1, lanes 3, 5, and 7). Yee et al. (2008) also observed that nonpolar lipids were reduced and polar phospholipids were concentrated in cow milk cheese after SFE with $\mathrm{CO}_{2}$, and that only nonpolar lipids and cholesterol were extracted during the process. Astaire et al. (2003) and Costa et al. (2010) reported similar findings and reached a similar conclusion when working with buttermilk powder samples.

There is immense interest in developing low-cholesterol foods, as reflected by the large number of lowcholesterol products available in the market, and new trends are focused on nutraceutical products (Bernal et al., 2011) in natural matrices, especially in dairy products (Turgeon and Rioux, 2011). The goat cheese resulting after SFE treatment is an excellent product with all the healthy benefits of goat milk, as well as an increase in phospholipids content on fat basis and a decrease in triglyceride and cholesterol contents.

\section{Cheese Microstructure Analysis with CLSM}

Micrographs of cheese obtained with CLSM are presented in Figure 2. Fat is indicated by the letter "F" and protein with the letter "P", whereas the serum phase and pockets are black. Lopez et al. (2007) identified 4 forms of fat present in Emmental cheese: (1) intact milk fat globules, which are small, spherical globules dispersed throughout the cheese; (2) ag- 
a)

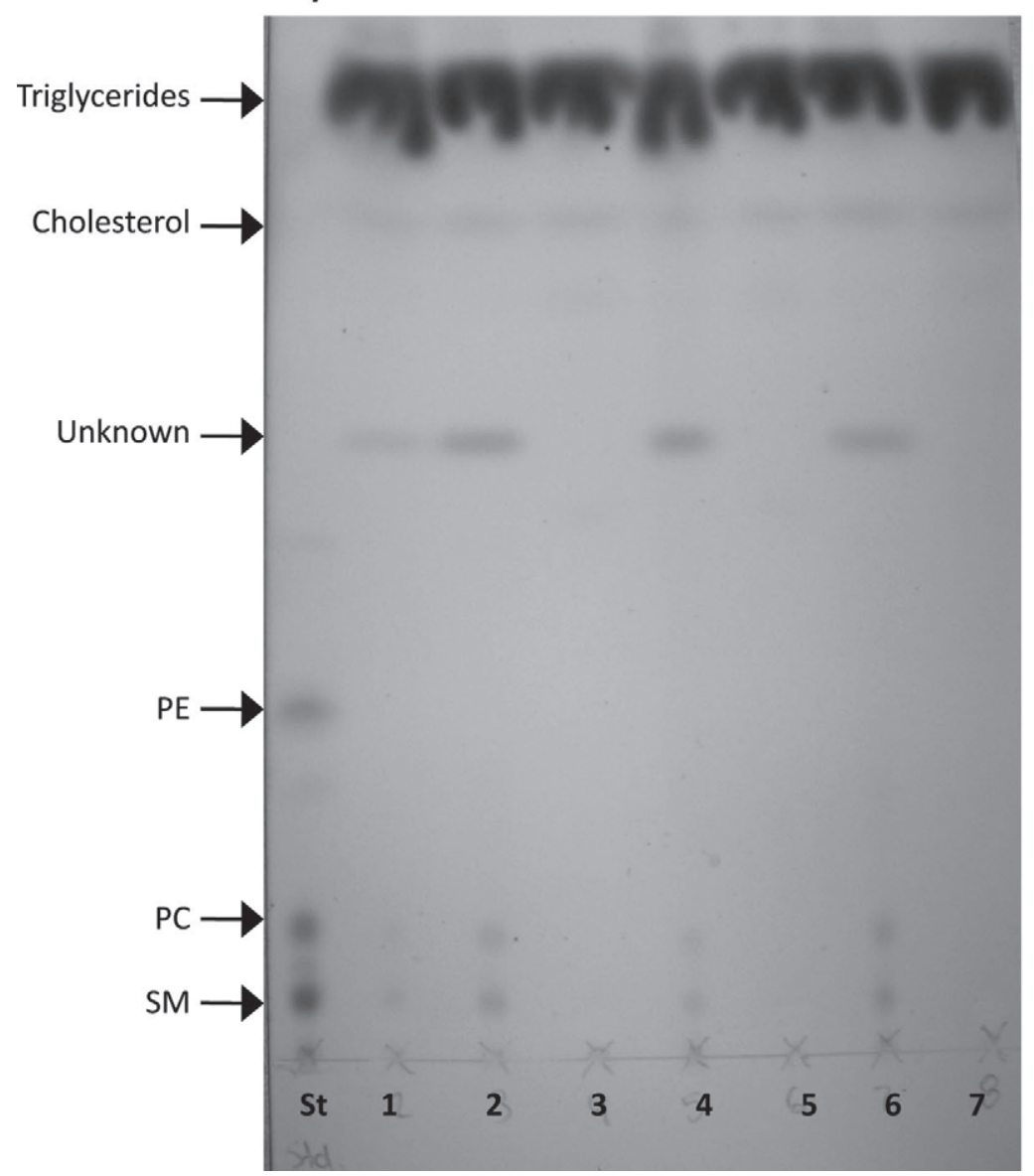

b)

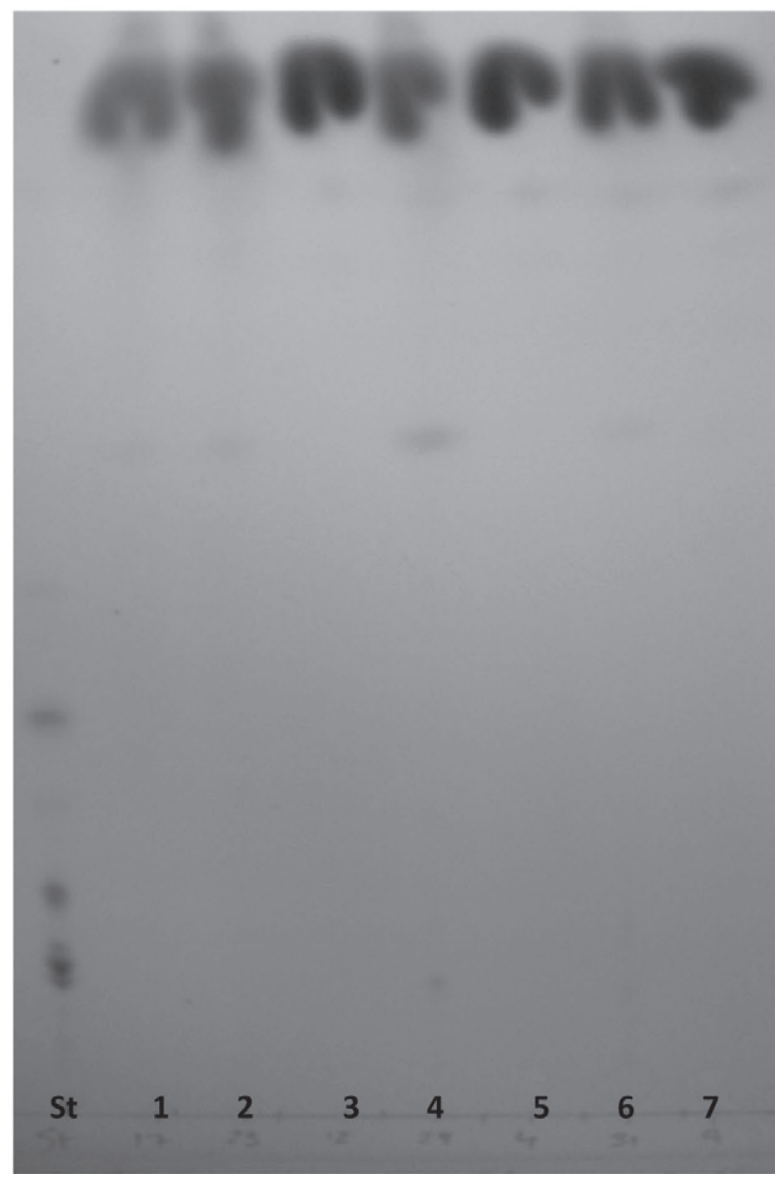

Figure 1. Thin layer chromatography plate showing the polar lipid profile of (a) Majorero and (b) Gouda-type cheeses. Control cheese (lane 1) and cheese treated with supercritical $\mathrm{CO}_{2}$ at 10 (lane 2), 30 (lane 4), and $40 \times 10^{6} \mathrm{~Pa}$ of pressure (lane 6). Residual extracted fat from cheese treated with supercritical $\mathrm{CO}_{2}$ at 10 (lane 3), 30 (lane 5), and $40 \times 10^{6} \mathrm{~Pa}$ of pressure (lane 7). St $=$ standard; $\mathrm{PE}=$ phosphatidylethanolamine; $\mathrm{PC}=$ phosphatidylcholine; $\mathrm{SM}=$ sphingomyelin .

gregates of milk fat globules that appear as clumps of circular globules; (3) coalesced milk fat globules, which are spherical but larger than the typical milk fat globules; and (4) nonglobular fat or free fat. All of these forms were identified in the micrographs in the current study.

In the control Majorero cheese, fat appeared to have a coalesced or nonglobular appearance in the whey pockets. Small, intact milk fat globules were especially visible in Majorero cheeses treated at $10 \times 10^{6} \mathrm{~Pa}$. With increasing pressure, the fat globules appear first as aggregated (P20), and then they became coalesced (P30), before finally appearing as very small and spherical globules coexisting with coalesced ones (P40). This evolution of fat globule appearance could be caused by the increase in applied pressure, which favors the aggregation and coalescence of the fat. The final state of fat in P40 Majorero cheeses could be produced by the disruption of fat into smaller globules due to SFE of fat. In Gouda-type control cheese, as well as in P10 cheeses, fat appeared as nonglobular fat. In P20 and P40 Gouda-type cheeses, the fat coexisted in small globules with coalesced globules, whereas the fat appeared to be coalesced in the images of P30 cheeses.

Rogers et al. (2010), working with low-fat Cheddar cheese, reported that CLSM images of cheese microstructure showed increasing fat globule size with increasing cheese fat content. Specifically, low-fat cheeses (3-8\% fat) had more spherical fat globules dispersed throughout the protein matrix, whereas cheeses with 28 to $33 \%$ fat had clumped and coalesced fat globules forming nonspherical shapes. Gunasekaran and Ding (1999) examined the fat globules in 1-mo-old Cheddar of varying fat contents (4-30\%) and detected the smallest size and greatest quantity of fat globules in cheeses with the lowest fat content. The average globule size appeared to be inversely related to the total fat content of the cheese. In contrast, cheeses with 28 to $33 \%$ fat 
Majorero
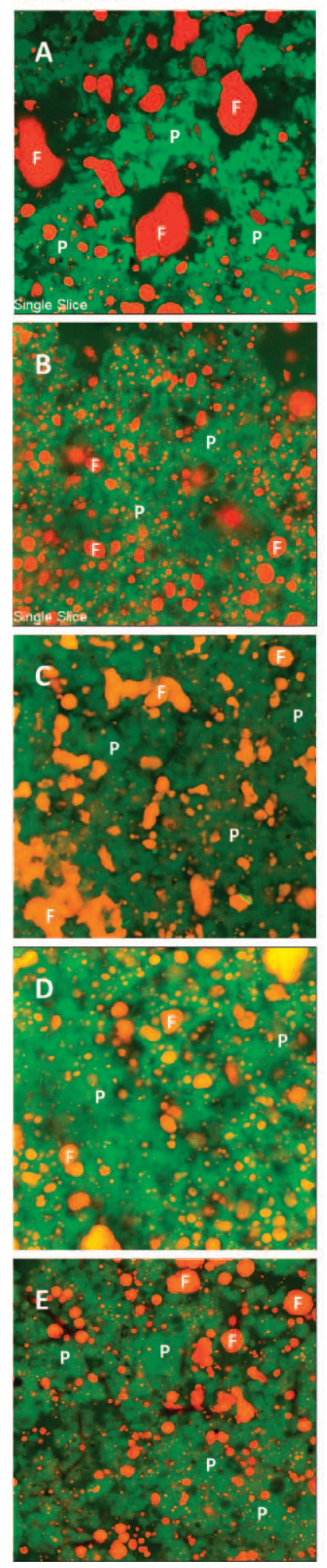

Figure 2. Confocal laser scanning micrographs of Majorero and goat Gouda-type control cheese (A), and cheese treated with supercritical $\mathrm{CO}_{2}$ at $10(\mathrm{~B}), 20(\mathrm{C}), 30(\mathrm{D})$, and $40(\mathrm{E}) \times 10^{6} \mathrm{~Pa}$ of pressure. Fat is orange $(\mathrm{F})$ and protein green $(\mathrm{P})$; the serum phase is black. Color version available in the online PDF.

\section{Gouda}
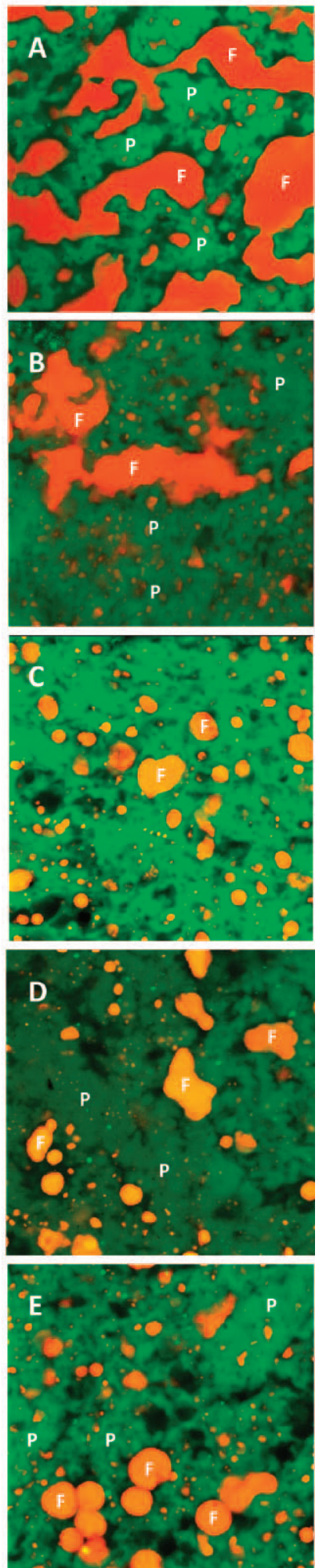

had clumped and coalesced fat globules forming nonspherical shapes. Gunasekaran and Ding (1999) noted that the nature of protein matrix in low-fat cheese may influence fat globules by preventing changes in their size and shape. Guinee et al. (2000) also examined the microstructure of Cheddar cheeses with fat contents in the range from 7 to $30 \%$ using CLSM. Reduction of fat content of cheese was accompanied by dispersion of discrete globules without clumping, whereas increasing fat content of cheese resulted in progressive clumping and coalescence of the globules.

Heating of the curd grains is part of the cheese-making process for Gouda but not Majorero and could explain the presence of large fat globules in the control goat Gouda-type cheeses compared with the control Majorero cheese. Lopez et al. (2007) observed that heating the curd grains induced formation of fat globule aggregates and that pressing of the curd grains resulted in the greatest disruption of milk fat globules, including their coalescence and the formation of nonglobular (free) fat. Guinee et al. (2000) attributed the clumping and coalescing of globules to the destruction of the milk fat globule membrane during processing and to the heating of curds during Cheddar cheese-making. The shape of fat in control Gouda-type cheese images obtained with CLSM in this study and the lower phospholipids content found in the thin layer chromatography analysis are consistent with the stirring and heating of curd grains during the cheese-making process of this cheese type.

The control Majorero cheese demonstrated a greater number and size of whey pockets compared with the control goat Gouda cheese (Figure 2). The fat content in full-fat cheese acts as a breaker in the protein matrix and improves the chewability (Johnson et al., 2009); therefore, fat is an important component in cheesemaking to obtain a high quality cheese with a good texture. The more open matrix and whey pockets found in the control Majorero cheese could result from the greater amount of fat extracted in relation to the initial content and compared with the Gouda-type cheese. In addition, fat content was continuously decreasing as the pressure of $\mathrm{SC}_{-} \mathrm{CO}_{2}$ was increased. Lopez et al. (2007) also suggested that the increase in the density of the protein matrix during the grain stirring and heating (as in Gouda type cheese-making) decreases the size of the pores left in the cheese matrix by whey; hence, the fat can become too large and act as breakers in the protein matrix.

\section{Microbial Counts}

Results of bacterial counts obtained from Majorero and goat Gouda-type cheeses are summarized in Table 
Table 3. Effects of different treatments on the total aerobic, lactococci, and lactobacilli counts (log cfu)

\begin{tabular}{|c|c|c|c|c|c|c|c|}
\hline \multirow[b]{2}{*}{ Item } & \multicolumn{6}{|c|}{ Treatment $^{1}$} & \multirow[b]{2}{*}{ SEM } \\
\hline & Control & CI & $\mathrm{P} 10$ & P20 & P30 & $\mathrm{P} 40$ & \\
\hline \multicolumn{8}{|l|}{ Majorero cheese } \\
\hline Aerobic bacteria & $5.38^{\mathrm{a}}$ & $5.06^{\mathrm{ab}}$ & $3.93^{\mathrm{b}}$ & $3.24^{\mathrm{b}}$ & $2.66^{\mathrm{b}}$ & $3.28^{\mathrm{b}}$ & 0.48 \\
\hline Lactococci & $9.28^{\mathrm{a}}$ & $8.78^{\mathrm{a}}$ & $7.43^{\mathrm{b}}$ & $7.22^{\mathrm{b}}$ & $6.97^{\mathrm{b}}$ & $4.27^{\mathrm{c}}$ & 0.55 \\
\hline Lactobacilli & $8.70^{\mathrm{a}}$ & $8.53^{\mathrm{a}}$ & $6.19^{\mathrm{b}}$ & $5.65^{\mathrm{bc}}$ & $5.19^{c}$ & $4.39^{\mathrm{d}}$ & 0.22 \\
\hline \multicolumn{8}{|c|}{ Goat Gouda-type cheese } \\
\hline Aerobic bacteria & $6.15^{\mathrm{a}}$ & $6.09^{\mathrm{a}}$ & $2.96^{\mathrm{c}}$ & $3.47^{\mathrm{bc}}$ & $3.60^{\mathrm{b}}$ & $3.55^{\mathrm{b}}$ & 0.19 \\
\hline Lactococci & $5.53^{\mathrm{a}}$ & $5.46^{\mathrm{a}}$ & $2.73^{\mathrm{c}}$ & $3.17^{\mathrm{bc}}$ & $3.27^{\mathrm{b}}$ & $3.52^{\mathrm{b}}$ & 0.18 \\
\hline Lactobacilli & - & - & - & - & - & - & - \\
\hline
\end{tabular}

3. The initial microbial counts in goat Gouda-type cheese were 6.15 and $5.53 \log$ for total aerobic bacteria and lactococci, respectively. No lactobacilli was found in this cheese. In Majorero cheese, the initial counts were $5.38,9.28$, and $8.70 \mathrm{log}$, for total aerobic bacteria, lactococci, and lactobacilli, respectively. An interesting observation was that in Majorero cheese samples, lactococcus and lactobacillus counts were always higher than aerobic bacteria population. In contrast, in goat Gouda-type cheese samples, aerobic bacteria counts were higher than lactococcus counts.

Lethality in goat Gouda-type cheese was 2 to $3 \operatorname{logs}$ after SFE treatment, and the highest reduction was observed at $10 \times 10^{6} \mathrm{~Pa}$. In contrast, in Majorero cheese, lethality increased as pressure of the SFE with $\mathrm{CO}_{2}$ was increased, varying from 1.5 to 5 logs of reduction. For lactobacilli and lactococci counts, the highest reduction was at $40 \times 10^{6} \mathrm{~Pa}$, whereas for total plate aerobic bacteria count, the highest reduction was at $30 \times 10^{6}$ Pa. Spilimbergo et al. (2009) reported a progressive permeabilization of the cell during treatment at $10 \times$ $10^{6} \mathrm{~Pa}$ and $36^{\circ} \mathrm{C}$. Their data evidenced a correlation between cellular death and $\mathrm{CO}_{2}$ permeabilization inside the cell. They reported that the initial damage to the cellular envelope is not lethal for the cell, after about 4 min of treatment, the fraction of surviving cells is still nearly $100 \%$, but after $10 \mathrm{~min}$, the treatment induces irreversible damage that ultimately causes cell death. The amount of $\mathrm{CO}_{2}$ accumulated in the lipid phase may then structurally and functionally disrupt the cell membrane because of an order loss of the lipid chain, which may increase the fluidity (Isenschmid et al., 1995).

The results found in the current study may be related to the responses based on microstructure of the cheeses, as discussed above. The lack of whey pockets and a closer matrix in the Gouda-type cheese might have blocked the $\mathrm{SC}-\mathrm{CO}_{2}$ from penetrating into the matrix, which limited the potential microbial inactiva- tion, unlike in the Majorero cheese, where microbial populations decreased with increasing pressure.

The main advantage of extraction with $\mathrm{SC}-\mathrm{CO}_{2}$ is that it is not a thermal treatment. Thus, SFE treatment could extend the shelf life of the product in the market while retaining all the original nutritional and organoleptic properties of untreated cheeses. However, more experiments need to be conducted to confirm this potential.

Yee et al. (2007) found, by GC-MS, that removal of fat with $\mathrm{SC}-\mathrm{CO}_{2}$ resulted in the partitioning of watersoluble flavor compounds between the cheese matrix and the lipids extracted, and a greater number of flavors were detected in the treated cheese matrix. Analysis of the water-soluble compounds in Cheddar and Parmesan cheeses indicated that cheeses treated with SFE did not differ from the control cheeses; however, 2 additional volatile sulfur compounds - dimethyl trisulfide and methional - were detected after treatment. A triangle test performed by Yee et al. (2007) indicated that panelists could identify the difference between the full-fat and $\mathrm{SC}-\mathrm{CO}_{2}$ treated Cheddar cheese, but could not differentiate among the Parmesan samples. Preference tests similarly indicated that panelists actually preferred the SFE-treated Parmesan sample to the full-fat and commercial reduced-fat counterparts. Carunchia Whetstine et al. (2006) demonstrated that when fat was removed from aged full-fat Cheddar cheese most of the flavor compounds remained in the cheese and were not removed with the fat. An informal sensory analysis was made with the goat cheeses treated in the present experiment, and cheeses were found to be acceptable; however, it is necessary to conduct sensory and instrumental analyses to compare control and treated cheeses.

\section{CONCLUSIONS}

Supercritical fluid extraction with $\mathrm{CO}_{2}$ has great potential in the dairy industry and in commercial 
applications. Not only can we obtain cheese lower in fat, but the resultant cheese maintains the beneficial phospholipids content. At the same time, the microbial population is reduced considerably after SFE treatment, which may be a potential tool for a longer shelf life for this perishable product, thus avoiding economic losses. Majorero cheese obtained after SFE treatment is an excellent candidate as a lower fat goat cheese, being lower in triglycerides and cholesterol especially, with all the healthy benefits inherent to goat milk.

\section{REFERENCES}

AOAC International. 1995. Official Methods of Analysis. 16th ed. AOAC International, Arlington, VA.

Arul, J., R. Tardif, A. Boudreau, D. S. McGinnis, and R. W. Lencki. 1994. Solubility of milk fat triglycerides in supercritical carbon dioxide. Food Res. Int. 27:459-467.

Aryana, K. J., and Z. U. Haque. 2001. Effect of commercial fat replacers on the microstructure of low fat cheddar cheese. Int. J. Food Sci. Technol. 36:169-177.

Astaire, J. C., R. Ward, J. B. German, and R. Jiménez-Flores. 2003. Concentration of polar MFGM lipids from buttermilk by microfiltration and supercritical fluid extraction. J. Dairy Sci. 86:22972307.

Awad, S., A. N. Hassan, and K. Muthukamarappan. 2005. Application of exopolysaccharide-producing culture Cheddar cheese: Texture and melting properties. J. Dairy Sci. 88:4204-4213.

Bernal, J., J. A. Mendiola, E. Ibénez, and A. Cifuentes. 2011. Advances analysis of nutraceuticals. J. Pharm. Biomed. Anal. 55:758-774.

Bradley, R. L. J., E. Arnold, D. M. Barbano, R. G. Semerad, D. E. Smith, and B. K. Vines. 1992. Chemical and physical methods: Fat. Pages 433-531 in Standard Methods for the Examination of Dairy Products. R. T. Marshall, ed. American Public Health Association, Washington, DC.

Brown, J. A., E. A. Foegeding, C. R. Daubert, M. A. Drake, and M. Gumpertz. 2003. Relationships among rheological and sensorial properties of young cheese. J. Dairy Sci. 86:3054-3067.

Carunchia Whetstine, M. E., M. A. Drake, B. K. Nelson, and D. M. Barbano. 2006. Flavor profiles of full-fat and reduced-fat cheese and cheese fat made from aged Cheddar with the fat removed using a novel process. Food Hydrocoll. 25:1915-1924.

Childs, J., and M. A. Drake. 2009. Consumer perceptions of fat reduction in cheese. J. Sens. Stud. 24:902-921.

Costa, M. R., X. E. Elias-Argote, R. Jiménez-Flores, and M. L. Gigante. 2010. Use of ultrafiltration and supercritical fluid extraction to obtain a whey buttermilk powder enriched in milk fat globule membrane phospholipids. Int. Dairy J. 20:598-602.

Dabour, N., E. Kheadr, N. Benhamou, I. Fliss, and G. LaPointe. 2006. Improvement of texture and structure of reduced-fat Cheddar cheese by exopolysaccharide-producing lactococci. J. Dairy Sci. 89:95-110.

Drake, M. A. 2008. The impact of fat content on flavor of cheddar cheese. J. Dairy Sci. 91(E. Suppl. 1):152. (Abstr.)

Fresno, M., A. Rodríguez, A. Escudero, R. González, P. Calero, S. Menéndez, and S. Álvarez. 2008. ¿Es posible elaborar quesos de leche cruda sin riesgos sanitarios? Ejemplo de los quesos Majoreros y Palmeros. Pages 393-395 in Memorias IX Simposio Iberoamericano Sobre la Conservación y Utilización de Recursos Zoogenéticos, Mar de Plata, Argentina. R. D. Martínez, ed. CombiandCyted, Universidad Lomas de Zamora, Argentina.

Guinee, T., and P. L. H. McSweeney. 2006. Significance of milk fat in cheese. Pages 377-440 in Advanced Dairy Chemistry. Vol. 2: Lipids. 3rd ed. P. F. Fox and P. L. H McSweeney, ed. Springer Science, New York, NY.
Guinee, T. P., M. A. E. Auty, and M. A. Fenelon. 2000. The effect of fat content on the rheology, microstructure and heat-induced functional characteristics of Cheddar cheese. Int. Dairy J. 10:277-288.

Gunasekaran, S., and K. Ding. 1999. Three dimensional characteristics of fat globules in Cheddar cheese. J. Dairy Sci. 82:1890-1896.

Gwartney, E., E. A. Foegeding, and D. K. Larik. 2002. The texture of commercial full fat and reduced fat cheese. J. Food Sci. 67:812816.

Haenlein, G. F. W. 2004. Goat milk in human nutrition. Small Rumin. Res. 51:155-163.

Isenschmid, A., I. W. Marison, and U. von Stockar. 1995. The influence of pressure and temperature of compressed $\mathrm{CO}_{2}$ on the survival of yeast cells. J. Biotechnol. 39:229-237.

Jiménez-Gúzman, J., A. Flores-Nájera, A. E. Cruz-Guerrero, and M. García-Garibay. 2009. Use of an exopolisaccharide-producing strain of Streptococcus thermophilus in manufacture of Mexican Panela cheese. Food Sci. Technol. 42:1508-1512.

Johansen, S. B., T. Næs, and M. Hersleth. 2011. Motivation for choice and healthiness perception of calorie-reduced dairy products. A cross-cultural study. Appetite 56:15-24.

Johnson, M. E., R. Kapoor, D. J. McMahon, D. R. McCoy, and R. J. Narasimmon. 2009. Sodium and Fat levels in natural and processed cheeses: scientific and technological aspects. Comp. Rev. Food Sci. Food Safety 8:252-267.

Larsen, K. M. 2009. Effects of starch addition on low fat rennet curd properties and their partitioning between curd and whey. MS Thesis. Utah State University, Logan.

Lopez, C., B. Camier, and J. Y. Gassi. 2007. Development of the milk fat microstructure during the manufacture and ripening of Emmental cheese observed by confocal laser scanning microscopy. Int. Dairy J. 17:235-247.

MacGibbon, A., and M. Taylor. 2006. Composition and structure of bovine milk lipid. Pages 1-42 in Advanced Dairy Chemistry. Vol. 2. Lipids. 3rd ed. P. F. Fox and P. McSweeney, ed. Springer Science, New York, NY.

McMahon. D. J., M. C. Payne, R. L. Fife, and C. J. Oberg. 1996. Use of fat replacers in low fat Mozzarella cheese. J. Dairy Sci. 79:1911-1921.

Mistry, V. V. 2001. Low-fat cheese technology. Int. Dairy J. 11:413422

Nelson, B. K., and D. M. Barbano. 2004. Reduced-fat Cheddar cheese manufactured using a novel fat removal process. J. Dairy Sci. 87:841-853.

Nielsen, S. S. 2003a. Crude fat analysis. Pages 113-130 in Food Analysis. R. L. J. Bradley, ed. Kluwer Academic/Plenum Publishers, New York, NY.

Nielsen, S. S. 2003b. Moisture and total solids analysis. Pages 81-101 in Food Analysis. R. L. J. Bradley, ed. Kluwer Academic/Plenum Publishers, New York, NY.

Rahimi, J., A. Khosrowshahi, A. Madadlou, and S. Azarnia. 2007. Texture of low fat Iranian white cheese as influenced by gum tragacanth as a fat replacer. J. Dairy Sci. 90:4058-4070.

Raynal-Ljutovac, K., G. Lagriffoul, P. Paccard, I. Guillet, and Y. Chilliard. 2008. Composition of goat and sheep milk products: An update. Small Rumin. Res. 79:57-72.

Ribeiro, A. C., and S. D. A. Ribeiro. 2010. Specialty products made from goat milk. Small Rumin. Res. 89:225-233.

Rogers, N. R., D. J. McMahon, C. R. Daubert, T. K. Berry, and E. A. Foegeding. 2010. Rheological properties and microstructure of Cheddar cheese made with different fat contents. J. Dairy Sci. 93:4565-4576.

Rombaut, R., K. Dewettinck, and J. Van Camp. 2007. Phospho- and sphingolipid content of selected dairy products as determined by HPLC coupled to an evaporative light scattering detector (HPLCELSD). J. Food Compost. Anal. 20:308-312.

Salles, C., N. Sommerer, C. Septier, S. Issanchou, C. Chabanet, A. Garem, and J. L. Le Quere. 2002. Goat cheese flavor: Sensory evaluation of branched-chain fatty acids and small peptides. J. Food Sci. 67:835-841.

Sánchez-Macías, D., M. Fresno, I. Moreno-Indias, N. Castro, A. Morales-delaNuez, S. Álvarez, and A. Argüello. 2010. Physicochemi- 
cal analysis of full-fat, reduced-fat and low-fat artisan-style goat cheese. J. Dairy Sci. 93:3950-3956.

Sánchez-Macías, D., A. Morales-delaNuez, I. Moreno-Indias, L. E. Hernández-Castellano, V. Mendoza-Grimón, N. Castro, and A. Argüello. 2011. Lipolysis and proteolysis profiles of fresh artisanal goat cheese made with raw milk with 3 different fat contents. J. Dairy Sci. 94:5786-5793.

Sánchez-Macías, D., I. Moreno-Indias, S. Álvarez, M. Clevelan, N. Castro, A. Argüello, and M. Fresno. 2012. Sensory analysis of full, reduced- and low-fat cheese elaborated with raw goat milk. J. Appl. Anim. Res. 40:124-132.

Sousa, M. J., Y. Ardo, and P. L. H. McSweeney. 2001. Advances in the study of proteolysis during cheese ripening. Int. Dairy J. $11: 327-345$.

Spilimbergo, S., D. Mantoan, A. Quaranta, and G. Della Mea. 2009. Real-time monitoring of cell membrane modification during supercritical $\mathrm{CO}_{2}$ pasteurization. J. Supercrit. Fluids 48:93-97.

Spitsberg, V. L. 2005. Bovine milk fat globule membrane as a potential nutraceutical . J. Dairy Sci. 88:2289-2294.

Turgeon, S. L., and L. E. Rioux. 2011. Food matrix impact on macronutrients nutritional properties. Food Hydrocoll. 25:1915-1924.
Van Horn, L., and N. A. Ernest. 2001. Summary of the science supporting the new National Cholesterol Education Program dietary recommendations: What dietitians should know. J. Am. Diet. Assoc. 101:1148-1154.

Watts, G. F., P. Jackson, V. Burke, and B. Lewis. 1996. Dietary fatty acids and progression of coronary artery disease in men. Am. J. Clin. Nutr. 64:202-209.

Yates, M. D., and M. A. Drake. 2007. Texture properties of Gouda cheese. J. Sens. Stud. 22:493-506.

Yee, J. L. 2006. Characterization of supercritical fluid extraction of lipids from grated cheese. MS Thesis. California Polytechnic State University, San Luis Obispo.

Yee, J. L., H. Khalil, and R. Jiménez-Flores. 2007. Flavor partition and fat reduction in cheese by supercritical fluid extraction: Processing variables. Lait 87:269-285.

Yee, J. L., J. Walker, H. Khalil, and R. Jiménez-Flores. 2008. Effect of variety and maturation of cheese on supercritical fluid extraction efficiency. J. Agric. Food Chem. 56:5153-5157. 